\title{
Biological studies of muscoid flies (Diptera) breeding in mollusc carrion in Southeast Asia
}

\author{
R. A. Beaver \\ School of Natural Resources, University of the South Pacific, Box 1168, Suva, Fiji
}

(Received: October 1, 1985)

Key words: snail carrion, muscoid flies, West Malaysia, Thailand.

\begin{abstract}
Ten species of muscoid Diptera (Anthomyiidae, Calliphoridae, Muscidae, Sarcophagidae) were bred from dead snails, Achatina fulica, in West Malaysia, and six species from the same habitat in Northern Thailand. Information is given on the breeding sites, pattern of occurrence, development times, hymenopteran parasitoids, and medical and veterinary importance of the species.
\end{abstract}

\section{INTRODUCTION}

In the tropics, vertebrate corpses are usually very quickly removed by carrion feeders, both vertebrates (e.g. jackals, vultures) and invertebrates (especially ants). Because of this rapid disappearance, Disney (1970) has suggested that one of the main breeding sites of carrion-breeding flies in the tropics, away from human habitations and refuse, may be the corpses of larger invertebrates, especially the larger snails. Snail corpses tend to remain available to the flies for longer than other carrion, and are often quite abundant in suitable areas. Some of the Diptera which breed in them are of medical or veterinary importance through their involvement in myiasis (James, 1947; Zumpt, 1965), or as vectors of pathogens (Greenberg, 1971; Harwood and James, 1979).

A common large snail in many tropical areas is the giant African snail, Achatina fulica Bowdich. Its large size and voracious appetite make it a destructive pest in gardens and vegetable farms (Mead, 1961, 1979). There are a number of records in the literature of Diptera bred from dead
Achatinidae (e.g. Disney, 1970, 1973; Mead, 1961; Senior-White et al., 1940), but no extensive investigations of the fauna have been made. In this short series of papers, I shall consider the biology and ecology of the Diptera and their Hymenopteran parasitoids bred from dead snails (chiefly $A$. fulica) in West Malaysia and Thailand. Here, I deal with 12 species from the muscoid families Anthomyiidae, Calliphoridae, Muscidae and Sarcophagidae. Nomenclature of the Diptera follows the Catalog of the Diptera of the Oriental Region (Delfinado and Hardy, 1977), except that more recent synonymy given by Lopes and Kano (1979) for some species of Sarcophagidae has been taken into account.

\section{Methods of Study}

Snails were killed by freezing, and exposed singly in plastic dishes with sand at the bottom. Each dish had a narrow inturned rim to prevent fly larvae from escaping, and was placed in a tray of water to exclude ants. A plastic cover above the tray excluded rain. After 1-7 days, the snails plus sand were placed in large kilner jars fitted with collection tubes, and the adult 
flies bred out. Total numbers of puparia of each species in the sand or inside the snail were counted after emergences were complete. Records given below of the numbers of individuals produced by a snail are based on the numbers of puparia found.

In West Malaysia, five experiments were carried out on a site in the campus of Universiti Sains Malaysia on the island of Penang, about $1 \mathrm{~km}$ from the sea. From 13-45 dead Achatina fulica were used in different experiments. In Thailand, the experimental site was on the campus of Chiang Mai University in the North of the country. Two experiments were carried out, one using dead A. fulica, and the other using in addition, two smaller species of snail, Vivipara japonica Mart., and Indoplanorbis sp. The snails of each species were selected to be of nearly the same size within each experiment, but some variation occurred between experiments.

\section{Biology of the Diptera}

Anthomyiidae

\section{Anthomyia illocata (Walker)}

This species is widely distributed in the tropical and subtropical parts of the Oriental region and in the Pacific. It typically breeds in garbage and decaying carrion (Kano et al., 1968; Roy and Dasgupta, 1975). I bred the species in West Malaysia from 7 snails. From 1-3 individuals were bred per snail. Adults emerged from 14-24 days after the snails were exposed (Table 2). The chalcid parasitoid, Brachymeria minuta (L.), was bred from one puparium.

\section{Calliphoridae}

\section{Phaenicia cuprina (Wiedemann)}

This is a widely distributed and wellknown species which is of great veterinary importance in Australia and Southern Africa as the principal species involved in primary strike of sheep (Zumpt, 1965). It is occasionally involved in human myiasis (James, 1947), and may cause myiasis of cattle and other domestic animals in tropical Asia (Senior-White et al., 1940; Roy and Dasgupta, 1975). The normal breeding site, however, in most areas is carrion or garbage, and the parasitic habit seems to have evolved secondarily (Zumpt, 1965). The biology and ecology of the species has been studied by many workers. A recent review is given by Kitching (1981). I bred the species from a single snail exposed for 7 days in West Malaysia. This produced 15 adults ( $ڤ 3$, 129). A further individual had been parasitised by Brachymeria minuta. Adults emerged over a short period, 16-19 days

Table 1 Percentage of Achatina fulica attacked by various fly species in West Malaysia.

\begin{tabular}{|c|c|c|c|c|c|c|}
\hline \multirow{2}{*}{ Species } & \multirow{2}{*}{$\begin{array}{l}\text { Experiment } \\
\text { number }\end{array}$} & \multicolumn{5}{|c|}{ Percentage of snails attacked } \\
\hline & & 1 & 2 & 3 & 4 & 5 \\
\hline \multicolumn{3}{|c|}{ Anthomyia illocata } & 20 & & 9 & \\
\hline Phaenicia cupr & & 8 & & & & \\
\hline \multicolumn{3}{|c|}{ Atherigona orientalis } & & & & 3 \\
\hline \multicolumn{2}{|c|}{ Fannia leucosticta } & 15 & 10 & 3 & 13 & 80 \\
\hline \multicolumn{2}{|c|}{ Ophyra chalcogaster } & & 10 & & & 3 \\
\hline \multicolumn{2}{|c|}{ Boettcherisca peregrina } & 8 & 5 & & 2 & \\
\hline \multicolumn{2}{|c|}{ Parasarcophage brevicornis } & 23 & 10 & & & \\
\hline \multicolumn{2}{|c|}{$P . d u x$} & 100 & 100 & 79 & 100 & 100 \\
\hline \multicolumn{2}{|c|}{ Phytosarcophaga gressitti } & 38 & & & & \\
\hline \multicolumn{2}{|c|}{ Seniorwhitea reciproca } & & 15 & & & \\
\hline \multicolumn{2}{|c|}{ Total No. of snails } & 13 & 20 & 28 & 45 & 30 \\
\hline \multicolumn{2}{|c|}{ Date of exposure } & 18.iv. 75 & 29.iv.75 & 7.ii.76 & 5.v.76 & 16.vi.77 \\
\hline \multicolumn{2}{|c|}{ Date of collection } & $25 . i v .75$ & $6 . v .75$ & 8-12.ii.76 & $6-12 . v .76$ & 23.vi.77 \\
\hline
\end{tabular}


Table 2 Number of individuals pupated per attacked snail (mean and range) and time in days (mean and range) between exposure of the snail and emergence of the adult flies for various fly species in West Malaysia.

\begin{tabular}{lcc}
\multicolumn{1}{c}{ Species } & No. of individuals & No. of days \\
\hline Anthomyia illocata & $1.6(1-3)$ & $19.4(14-24)$ \\
Phaenicia cuprina & 16 & $17.7(16-19)$ \\
Atherigona orientalis & 4 & $17.2(16-19)$ \\
Fannia leucosticta & $7.3(1-34)$ & $20.6(15-34)$ \\
Ophyra chalcogaster & $18.3(4-43)$ & $24.2(17-30)$ \\
Boettcherisca peregrina & $3.3(1-6)$ & $16.4(15-19)$ \\
Parasarcophaga brevicornis & $3.4(2-6)$ & $25.3(18-32)$ \\
P. dux & $41.9(1-108)$ & $17.0(13-32)$ \\
Phytosarcophaga gressitti & $5.0(2-11)$ & $17.1(15-18)$ \\
Seniorwhitea reciproca & $4.3(1-8)$ & $23.8(21-27)$
\end{tabular}

after exposure of the snail.

Muscidae

\section{Atherigona orientalis (Schiner)}

This is a cosmotropical species which breeds in almost any dead organic matter. It may be an important carrier of faecal pathogens (Bohart and Gressitt, 1951; Pont, 1973). The larvae are facultative predators on the larvae of the other insects in the same substrate (Deeming, 1971, 1979). The species has been bred from dead achatinid snails in Cameroon (Disney, 1970) and Zambia (Beaver, 1986). I bred $A$. orientalis in West Malaysia from only a single snail. Four adults emerged 16-19 days after the snail was exposed (Table 2). There was no obvious effect on the numbers on individuals of other Diptera bred from the same snail. Fannia leucosticta (Meigen)

This is a widely distributed synanthropic species which breeds chiefly in excreta and carrion, and may be of hygienic importance in the tropics (Pont, 1973). Greenberg (1973) reviews earlier biological information on this and related species. F. leucosticta does not appear to have been bred before from dead snails. I bred the species from dead Achatina fulica in both Thailand and Malaysia. In the latter country, the species occurred in all experiments (Table 1), and up to 34 individuals were bred from a single snail. The species did not occur in snails which were taken to the laboratory less than 3 days after exposure. Like Fannia canicularis (L.) (Beaver, 1972), the species may prefer to oviposit in older and drier carrion. The larvae often pupate within the snail, but usually near the entrance, and not within the inner whorls. Adults emerged from 15-34 days after exposure of the snails (Table 2), with a minimum development period from egg to adult of 13 days.

\section{Ophyra chalcogaster (Wiedemann)}

This is a common species throughout the Oriental and Australasian regions. It has been reared from a variety of dead organic material, including both carrion and vertebrate faeces (Bohart and Gressitt, 1951; Kano et al., 1968; Roy and Dasgupta, 1975). The adults may be of great hygienic importance in the tropics as vectors of faecal pathogens (Pont, 1973). The larvae, like those of other species of Ophyra, are facultative predators of other dipteran larvae in the breeding sites (Skidmore, 1973; Van Emden, 1965). I bred the species from dead Achatina fulica in both Thailand and Malaysia. In Malaysia, although adults were frequently captured in nearby areas, it was bred from only three snails. This suggests that the main breeding sites were elsewhere. The snails produced 4, 8 and 43 individuals respectively. In the last case, over 30 individuals died as third instar larvae, or formed distorted puparia, possibly as a consequence of attacks by their fellows. The snail also contained 32 dead larvae of the sarcophagid, Parasarcophaga $d u x$, the majority of which had large holes 
in the body wall, and had evidently been predated-presumably by the Ophyra larvae. With the exception of one larva of Fannia leucosticta, larvae of other species in the snail (Chloropidae, Ephydridae, Phoridae) did not seem to have been attacked, but the remains of their smaller larvae could have been overlooked. Adults emerged from 17-19 days after exposure in the two snails with small numbers of Ophyra, but not until 25 -30 days after exposure in the snail with a high Ophyra population. The delay may have been related to competition for food among the larvae. Bohart and Gressitt (1951) give a development period of 14 days.

Sarcophagidae

\section{Boettcherisca peregrina (Robineau- Desvoidy)}

This is a common species in the Eastern Palearctic, Oriental and Australo-Pacific regions. It breeds in a wide variety of decomposing organic matter, including carrion and human faeces (Greenberg, 1971; Hall and Bohart, 1948; Kano et al., 1968; Roy and Dasgupta, 1975), and has been involved in human myiasis (James, 1947; Kani et al., 1981). In the palearctic, it is a synanthropic species of hygienic importance as a mechanical vector of disease organisms (Kano et al., 1968; Tumrasvin and Kano, 1979), but in West Bengal, it is reported never to enter houses, and rarely to settle on exposed food (Roy and Dasgupta, 1975). Presumably different genetic strains are involved. Further biological information is given by Buei et al. (1978). The species is recorded from dead Achatina fulica by Senior-White et al. (1940, as Sarcophaga fuscicauda Böttcher), but dead snails are probably not among its more important breeding sites. The species occurred rarely in dead $A$. fulica in Thailand, and in three out of five experiments in Malaysia, but only in a single snail in each experiment (Table 1). The numbers of individuals bred per snail varied from 1-6, and adults emerged from 15-19 days after exposure of the snails (Table 2).

\section{Parasarcophaga brevicornis (Ho)}

Little seems to be known of this Oriental species. Roy and Dasgupta (1975) report that it is attracted to dead fish and meat, and develops readily in such media. According to Tumrasvin and Kano (1979), it breeds in dead animals and garbage. It was bred in Malaysia from only five snails (Table 1), and in small numbers (Table 2). Adults emerged from 18-32 days after the snails were exposed. The parasitoid, Brachymeria minuta, was bred from one puparium.

\section{Parasarcophaga dux (Thomson)}

This is a widely distributed species, sometimes recorded as its synonym Parasarcophaga misera (auct. nec Walker) (Lopes and Kano, 1979). It normally breeds in carrion (Ameen and Huq, 1973; Hall and Bohart, 1948; James, 1947; Senior-White et al., 1940). However, it is also an important cause of myiasis in domesticated animals in India (Alwar and Seshiah, 1958; Roy and Dasgupta, 1975). It has also been recorded from human faeces (Bohart and Gressitt, 1951), and has been found associated with the cause of amoebic dysentery, Entamoeba histolytica (Greenberg, 1971). It is recorded from dead snails, including Achatina and Indoplanorbis by Senior-White et al. (1940) and Séguy (1941), and was the commonest species collected from land snails on Guam by Bohart and Gressitt (1951).

$P$. $d u x$ was by far the commonest sarcophagid bred from the dead snails in both Thailand and Malaysia. In Thailand, I bred it from Achatina fulica, Indoplanorbis sp. and Vivipara japonica. It was bred from almost all snails exposed to attack (Table 1). Of the unattacked snails in Malaysia, five were exposed for only $24 \mathrm{hr}$, and one for 2 days. Larviposition was observed to start almost immediately the snails were exposed. According to Alwar and Seshiah (1958), the female usually deposits 29-35 larvae at one time. I found up to 66 puparia in snails exposed for only 1 day. The maximum number of individuals found in a snail was 108 (Table 2). As in other sarcophagids (Beaver, 1973), the size of the individuals decreases as the number per snail increases. The largest puparia measured had a volume of $101 \mathrm{~mm}^{3}$, and were found in two snails containing 6 and 14 puparia respectively. The smallest viable puparium had a volume of only $18 \mathrm{~mm}^{3}$, and occurred in a snail containing 87 puparia. The mini- 
mal development period given by Alwar and Seshiah (1958) is 11 days, but this was at higher ambient temperatures (above $30^{\circ} \mathrm{C}$ ) than occurred in Penang. Bohart and Gressitt (1951) give a development period in Guam of 16 days. In Penang, adults emerged from 13-32 days after the snails were exposed (Table 2). More than 50\% of the emergences occurred on days 13-16 after exposure, and there was a long 'tail' of later emergences. According to Alwar and Seshiah (1958), at least 7 days must elapse before the newly emerged female can larviposit.

Five species of parasitoid were bred from the puparia: Brachymeria minuta, B. podagrica (F.) (Chalcididae) in both Thailand and Malaysia; Spalangia endius Walker, Spalangia sp. (Pteromalidae), and Exoristobia philippinensis Ashmead (Encyrtidae) in Malaysia only.

\section{Parasarcophaga idmais (Séguy)}

This species is closely related to $P$. $d u x$ and $P$. brevicornis, and is known only from China, Nepal and Thailand. Nothing seems to have been recorded of its biology. I bred the species from dead Achatina fulica in Northern Thailand. It occurred in several snails, but was much less abundant than $P$. dux. No further details are available due to early confusion with $P$. $d u x$ in the experiments.

\section{Parasarcophaga spinipenis Shinonaga and}

\section{Tumrasvin}

This species was recently described (Shinonaga and Tumrasvin, 1979) from specimens collected in Thailand, and is known only from that country. It has been collected at decaying meat in the forest. A small number of specimens were bred from dead Achatina fulica at Chiang Mai. There are no other breeding records.

\section{Phytosarcophaga gressitti (Hall and Bohart)}

This species seems to be commonest in the Pacific islands, but is also known from Thailand and the Philippines (Tumrasvin and Kano, 1979). I know of no previous published records from West Malaysia. It is a species of the seashore, and it may be noted that the experimental area in Penang was only $1 \mathrm{~km}$ from the shore. P. gressitti typically breeds in carrion (Hall and Bohart, 1948; Bohart and Gressitt, 1951). The latter authors bred it commonly from dead snails, and consider it one of the ten most important species found in Guam in the transmission of faecal-borne diseases. I bred the species in West Malaysia in only one experiment, but from $38 \%$ of the snails (Table 1). From 2-11 individuals were bred from each snail. Adults emerged from 1518 days after the snails were exposed (Table 2). Bohart and Gressitt (1951) give a developmental period of 13 days.

\section{Seniorwhitea reciproca (Walker)}

Most references to this species are to its synonyms Sarcophaga krameri Böttcher, and $S$. orientaloides Senior-White (Lopes and Kano, 1979). It is a common species in the Oriental region, and has been bred mostly from invertebrate carrion (including dead Achatina fulica), although also recorded as parasitic (Senior-White et al., 1940). I bred the species from dead $A$. fulica in both Thailand and Malaysia. In Malaysia, it occurred in only one experiment (Table 1). Up to 8 individuals were present in a snail. Adults emerged from 21-27 days after the snails were exposed (Table 2 ). In one snail, seven of the eight puparia were parasitised by the pteromalid, Spalangia endius. Toyama and Ikeda (1976) record another species of Spalangia, $S$. cameroni Perkins, as a parasite in Hawaii.

\section{Discussion}

A dead snail offers a number of advantages to insects which use it for breeding. It forms a protected, humid, nutritionally rich source of food in which rapid development is possible, and which lacks active defense mechanisms. The disadvantages of the dead snail as a breeding site are that: 1) the dead snails are normally scattered widely in space and time, and hence not easy to locate; 2) they show rapid successional changes, and can only be colonized for a short period; 3 ) they have a limited energy supply which is soon used up by the inhabitants so that competition between them is common (Beaver, 1977, 1984). In nature, dead snails are exploited primarily by Dip- 
tera, and a considerable number of species have been recorded breeding in them. In West Malaysia, for example, 32 species of fly in 10 families were bred at one site; in the United Kingdom, 18 species in 9 families were bred at one site (Beaver, 1972). Few of these species seem to use the snails as their main or only breeding site, and none of the species considered in the present paper do so. The majority of species bred from dead snails also breed in other carrion, and often in a variety of dead organic matter. In view of the disadvantages of the habitat mentioned above, this polyphagy is not surprising. Polyphagy is a good method of reducing the apparent heterogeneity of the environment from the point of view of the fly (Beaver, 1977). However, it also contributes to the medical and veterinary importance of the flies as vectors of disease organisms. An individual that travels widely between different types of habitat, alighting and feeding on garbage, carrion, human food, etc., is far more likely to act as a vector than one which confines its visits to, say, dead molluscs. Of the twelve species covered in the present paper, eight are recorded as disease vectors of some importance.

\section{Acknowledgements}

I am greatly indebted to Dr. S. Shinonaga for identifying most of the Diptera, and to Dr. $\mathbf{Z}$. Boucek and Dr. J. S. Noyes for identifying the parasitic Hymenoptera. I am grateful to the Department of Biology, Chiang Mai University, and the School of Biological Sciences, Universiti Sains Malaysia for providing facilities in Thailand and Malaysia respectively.

\section{REFERENCES}

Alwar, V. S. and S. Seshiah (1958): Studies on the life history and bionomics of Sarcophaga dux Thomson 1868. Indian Vet. J., 35: 559565.

Ameen, M. and M. F. Huq (1973): Fifth inhabiting flies of Dacca city. J. Nat. Hist., 7: 633-652.

Beaver, R. A. (1972): Ecological studies on Diptera breeding in dead snails. 1. Biology of the species found in Cepaea nemoralis (L.). Entomologist, 105: 41-52.

Beaver, R. A. (1973): The effects of larval com- petition on puparial size in Sarcophaga spp. (Diptera: Sarcophagidae) breeding in dead snails. J. Entomol. (A), 48: 1-9.

Beaver, R. A. (1977) : Non-equilibrium 'island' communities: Diptera breeding in dead snails. J. Anim. Ecol., 46: 783-798.

Beaver, R. A. (1984): Insect exploitation of ephemeral habitats. S. Pacific J. Nat. Sci., 6: $3-47$.

Beaver, R. A. (1986): Some Diptera and their parasitoids bred from dead snails in Zambia. Entomologist's Mon. Mag. (in press).

Bohart, G. E. and J. L. Gressitt (1951): Filthinhabiting flies of Guam. Bull. B.P. Bishop Mus., 204: $1-152+17$ pl.

Buei, K., S. H. Park and H. Yamugi (1978): Bionomics of three species of fleshflies, Boettcherisca peregrina, Parasarcophaga similis and $P$. crassipalpis with reference to the effects of temperature on development and fecundity. Jpn. J. Sanit. Zool., 29: 125-132.

Deeming, J. C. (1971): Some species of Atherigona Rondani (Diptera, Muscidae) from Northern Nigeria, with special reference to those injurious to cereal crops. Bull. Entomol. Res., 61: 133-190.

Deeming, J. C. (1979): New and little known species of Atherigona Rondani (Dipt., Muscidae) from Nigeria and Cameroon. Entomologist's Mon. Mag., 114 (1978) : 31-52.

Delfinado, M. D. and D. E. Hardy (1977): $A$ Catalog of the Diptera of the Oriental Region, Vol. III, Suborder Cyclorrhapha (excluding Division Aschiza), 854 pp., University Press of Hawaii, Honolulu.

Disney, R. H. L. (1970): A note on Discomyza similis lamb (Dipt., Ephydridae) and other flies reared from dead snails in Cameroon. Entomologist's Mon. Mag., 105 (1969) : 250-251.

Disney, R. H. L. (1973): A note on some filthinhabiting flies of Cameroon. Entomologist's Mon. Mag., 108 (1972) : 212-213.

Greenberg, B. (1971): Flies and Disease, Vol. 1, Ecology, Classification and Biotic Associations, 856 pp., Princeton University Press, Princeton, New Jersey.

Greenberg, B. (1973): Flies and Disease, Vol. 2, Biology and Disease Transmission, 447 pp., Princeton University Press, Princeton, New Jersey.

Hall, D. G. and G. E. Bohart (1948): The Sarcophagidae of Guam (Diptera). Proc. Entomol. Soc. Wash., 50: 127-135.

Harwood, R. F. and M. T. James (1979): Entomology in Human and Animal Health, 7th ed., 548 pp., Macmillan Publishing Go., New York. 
James, M. T. (1947): The flies that cause myiasis in man. U.S.D.A. Misc. Publ., 631: 1-175.

Kani, A., O. Nakamura, H. Ōno, K. Nagase, T. Totani, T. Morishita, K. Koyama and S. Iwata (1981): A case report, external myiasis of Boettcherisca peregrina. Jpn. J. Sanit. Zool., 32: 23-28.

Kano, R., K. Kaneko and S. Shinonaga (1968): Synanthropic flies in Hong Kong. Kontyu, 36 : 75-87.

Kitching, R. L. (1981): The sheep blowfly--a resource-limited specialist. In: Ecology of Pests. Some Australian Case Histories (eds. Kitching, R. L. and R. E. Jones), pp. 193-214. CSIRO, Australia.

Lopes, H. de S. and R. Kano (1979): On the types of some Oriental species of Sarcophagidae (Diptera) described by Francis Walker. Rerita Bras. Biol., 39: 305-317.

Mead, A. R. (1961): The Giant African Snail. A Problem in Economic Malacology, 257 pp., University of Chicago Press, Chicago.

Mead, A. R. (1979): Pulmonates, Vol. 2B, Economic Malacology, with Particular Reference to Achatina fulica, 150 pp., Academic Press, New York.

Pont, A. C. (1973): Muscidae (House-flies, Stable-flies, etc.). In: Insects and Other Arthropods of Medical Importance (ed., Smith, K. G. V.), pp. 251-277, British Museum (Natural History), London.

Roy, P. and B. Dasgupta (1975): Seasonal occurrence of muscid, calliphorid and sarcophagid fies in Siliguri, West Bengal, with a note on the identity of Musca domestica L. Oriental Ins., 9: 351-374.

Séguy, E. (1941): Études sur les mouches parasites. II. Calliphorides. Encycl. Entomol. Sér. A, 21: 1-436.

Senior-White, R., D. Aubertin and J. Smart (1940): The Fauna of British India, Including the Remainder of the Oriental Region. Diptera, Vol. VI, Calliphoridae, 283 pp., Taylor \& Francis Ltd., London.

Shinonaga, S. and W. Tumrasvin (1979): Two new genera and ten new species of the sarcophagid flies from Thailand (Diptera: Sarcophagidae). Jpn. J. Sanit. Zool., 30: 135-145.

Skidmore, P. (1973): Notes on the biology of palearctic muscids. Entomologist, 106: 25-59.

Toyama, G. M. and J. K. Ikeda (1976): An evaluation of fly breeding and fly parasites at animal farms on lecward and central Oahu. Proc. Hawaii, Entomol. Soc., 22: 353-368.

Tumrasvin, W. and R. Kano (1979): Studies on medically important flies in Thailand. 6. Report on 48 species of sarcophagid flies, including the taxonomic keys (Diptera: Sarcophagidae). Bull. Tokyo Med. Dent. Univ., 26: 149-179.

Van Emden, F. I. (1965): The Fauna of India and the Adjacent Countries. Diptera, Vol. 7, Muscidae, Part 1, 647 pp., Government of India, Delhi.

Zumpt, F. (1965): Myiasis in Man and Animals in the Old World, 267 pp., Butterworths, Iondon.

\section{摘 要}

東南アジアに扔ける貝類の死骸より 発生寸る八工類の生物学的研究

西アレーシアに祝いて，アフリカマイマイ Acha-

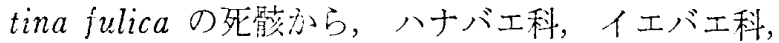
クロバェ科，ニクバエ科に属与る有弁類八工類10種䘮 得た。立た，北部多イだ同様にアフリカマイマイ， ヒシマキタトの一種 Indoplanorbis sp., オオタニシ Vivipara japonica の死娟より6種の八工艾得た。こ れ与汇つに一, 発生源と之の種類, 発育速度, 寄生蜂 汇ついて報留したほか，人紊衛生上の重要性につい下 も論じた。 